\title{
The Relationship between Cyber bullying and Intellectual Security of university youth
}

Anwaar. R. Mohammed Elsayed (Ph.D.) Associate professor of social work fields Faculty of social work- Helwan University 
The Egyptian Journal of Social Work (EJSW) https://ejsw.journals.ekb.eg/e ISSN: 2356-9204 Vol 11, Issue.1, January2021 
The Egyptian Journal of Social Work (EJSW) https://ejsw.journals.ekb.eg/e

ISSN: 2356-9204

Vol 11, Issue.1, January2021

\section{Abstract:}

The study aimed to determine the relationship between Cyber bullying and Intellectual Security of university youth, and trying to identify indicators of role of the social worker in social work to promote the Intellectual Security and facing Cyber bullying of university youth. The study has been applied to (378) practical faculties and theoretical faculties, males (142) and females (236).

The study concluded that there is a negative correlation that is statistically significant at (0.1) between Cyber bullying and the Intellectual Security of university youth, and there are statistically significant differences between the averages of grades of the university youth at practical faculties and theoretical faculties on the scales of Cyber bullying and the Intellectual Security, while there are no statistically significant differences between the averages of grades of the university youth males and females at practical faculties on the Total Cyber bullying scale dimensions, The study has found indicators to promote the Intellectual Security of university youth and facing Cyber bullying .

Key words : Cyber bullying - Intellectual Security - university youth.

\section{Introduction:}

Youth is considered the heart and pulse of any state. The strength of a state is determined by the strength of its youth, because it is through youth that a state progresses and achieves its objectives. Hence, communities give attention to youth, providing them with comprehensive services through several institutions to meet their needs and address their problems. This age bracket needs special treatment, from a community development perspective, to ensure its social and economic progress (Ali, 2008, p. 259).

University youth is one of the social groups that the state is concerned with because it affects its safety and security. It is an age bracket interspersed with some characteristics of other age brackets. It is defined as the stage where an individual is freed of childhood experiences, and learns the new roles that s/he will lead as an adult. In this stage, experiences towards the future and the surrounding environment are still undefined (Al-Wageez, 1997, p. 333).

Where the number of students enrolled in higher education reached 3,030,754 students in 2016-17, the number of male students was 578,662 or $52.1 \%$, while the number of female students reached 145,202 or 47.1\%. (Central Agency for Public Mobilization and Statistics, 
The Egyptian Journal of Social Work (EJSW) https://ejsw.journals.ekb.eg/e

ISSN: 2356-9204

Vol 11, Issue.1, January2021

University youth are the human wealth that is able to meet the challenges in the present and in the future as well as they are able to change and modernize society under the conditions they live, the youth have the right to a safe life and access to all services under the technological progress that the world is living in the field of communication and the ability of systems and states to have an intellectual and cultural influence on the youth.( Abdul RahiM,2018,P.4)

Intellectual security is one of the branches of security, and in fact it is the basis for any security considering that if the individual has a sound wise thought he /she can face any invasion controlling him/her, and the university is part of the general social entity, which undoubtedly affects the university youth.

The university stage is one of the most important stages that is concerned with maintaining the intellectual security of its students and that achieving security is due to the role of the faculty staff member, curricula and university activities in addition to the related university administration and this was confirmed by the study (Abdullah, 2017)

Thus, the youth today face many challenges and global cultural changes, which is the true image of a intellectual invasion directed at the minds of the youth, as they are the hope of the nation to achieve progress of the society in the future and this invasion tries to create a spirit of rebellion against the cultural components, and this is confirmed by the study (Mohammed, 2013) and one of the most important means on which it depends is the social media through which the university youth may be exposed.

There are implications for the use of social networking sites on the intellectual security of university-level female students, as confirmed by the Study (Muaither, 2015).

And also a study Gad \&Ahmed(2019) concluded that there are no statistically significant differences between the mean scores of social work students (males and females) using social networking sites and their impact on the social dimension of intellectual security. Intellectual security is a vital, important and influential topic in the life and future of university youth, but today university youth face many challenges that may affect intellectual security, including cyber bullying, which is so obvious. Bullying is a serious social problem. It happens worldwide and can happen at any stage of a person's life, from childhood playground to high school, university and even at the workplace. The digital and information revolution has merged into a communications revolution People, especially students, have 
The Egyptian Journal of Social Work (EJSW) https://ejsw.journals.ekb.eg/e

ISSN: 2356-9204

Vol 11, Issue.1, January2021

embraced the Internet and other electronic devices such as mobile phones and PDAs. The potential for bullying via electronic communication tools has grown with the advancement in communication and information technology (Zhang\& Wee Land and Dick, 2010).This is what the Eid, (2019) study found, that cyber bullying causes many immoral behaviors of university youth, such as insult, threat, and defamation.

Also a study Magsi \&Agha and Magsi (2017) which she emphasized out to explore how female university students suffer from cyber bullying within their campuses. The data for this study was collected from 120 female students at four universities in Sindh province of Pakistan. The results show that the female students were threatened and blackmailed frequently in the university campuses. While, 45 percent of the students did not disclose such incidents to their families because of the fear of being considered immoral. Also, the study Basyouni \& Alharbi (2020) which concluded that there is a statistically significant correlation between the feeling of psychological loneliness and cyber bullying of undergraduate students.

Social work has a role in promoting the national identity of university youth and identifying the mechanisms used by the social worker to enhance the intellectual security of university youth, as confirmed by the study Awad (2017). The study Mansour (2017) has also highlighted the evaluation of the role that the university must play in achieving intellectual security from the point of view of students and the teaching staff. The general practice in social work has a role in developing the awareness of the university youth of intellectual security, represented by national belonging, moderate ideology, tolerance and citizenship development, as confirmed by the study (Jadallah, 2018).

\section{Research Problem:}

1- The research problem is determined in what a relationship between cyber bullying and Intellectual Security of university youth.

2- What indicators of the roles of social worker in promoting intellectual security and facing cyber bullying of university youth.

\section{Study Goals}

1- Determining the relationship between cyber bullying and Intellectual Security of university youth.

2- Identify indicators of the roles of social worker in promoting intellectual security and facing cyber bullying of university youth 
The Egyptian Journal of Social Work (EJSW) https://ejsw.journals.ekb.eg/e

ISSN: 2356-9204

Vol 11, Issue.1, January2021

Study hypotheses: The current research attempts to test the following hypotheses:

First Hypothesis: There is a statistically significant negative correlation between cyber bullying and Intellectual Security of university youth.

Second Hypothesis: There are statistically significant differences between the averages of grades of the university youth at practical faculties and theoretical faculties on the scale of Cyber bullying.

Third Hypothesis: There are statistically significant differences between the averages of grades of the university youth at practical faculties and theoretical faculties on the scale of the Intellectual Security.

Fourth Hypothesis: There are statistically significant differences between the averages of grades of the university youth males and females at practical faculties and theoretical faculties on the scale of Cyber bullying.

\section{Study Concepts:}

\section{Cyber bullying}

Defined as harassment using technology such as social websites (Myspace/Facebook), email, chat rooms, mobile phone texting and cameras, picture messages (including sexting), IM (instant messages), or blogs. Cyber bullying involves repeated harm willfully inflicted on another person through technology and can include teasing, name calling, hurtful stories, embarrassing pictures, lies, false rumors, mean or threatening notes, threats of violence or death, and other hurtful actions (Miller\&Hufstedler,2009.P.2).

definitions is "any behavior performed through electronic or digital media by individuals or groups that repeatedly communicates hostile or aggressive messages intended to inflict harm or discomfort on others ( Barlinska\& Szuster,2018.P.2).

Cyber bullying is defined in this study as the intentional and frequent electronic behavior, to which university youth are exposed, such as (defamation - exclusion, inconvenience, threat- sexual harassment.) It comes from a person that is generally unidentified, called the electronic bully who harms the university youth who are called the victim of bullying.

\section{Intellectual Security}

Defined intellectual security as: protecting students' ideas, minds and thoughts from every belief and wrong behavior that would pose a threat to the security and stability of society (Alosaimi\& Sufyani, 2018, P.156). 
The Egyptian Journal of Social Work (EJSW) https://ejsw.journals.ekb.eg/e

ISSN: 2356-9204

Vol 11, Issue.1, January2021

Intellectual Security is also defined as intellectual safety derived from student responses to their experience of safety or threat in college classrooms, and explores students' experience of intellectual safety in relation to epistemological development (Schrader, 2004, p.87).

Intellectual security is also defined as the integrity of university student perception of misconceptions and intellectual deviations. Thus, the university student achieves personal stability, through which society is strengthened socially, intellectually and psychologically, and has a significant positive impact on the follow-up of intermediate approaches to thinking (Abdel Jawad, 2017, p. 152).

Theoretical definition of intellectual security:, Preserving university youth's thoughts from wrong thoughts in order to achieve personal stability and prepare the individual as an effective member of society, and to fortify his mind with sound ideas related to the dimensions of intellectual security (citizenship, religious, intellectual, security, , moral

\section{Theories guiding the study:}

\section{- Cognitive theory:}

Cognitive theory seeks to teach clients to monitor negative effects in thinking, distorted thoughts, and to work to explain them and start changing the pattern of misconceptions associated with these ideas, to change the quality of life, to evaluate and follow up behavior, to use self-talk and to teach cognitive and behavioral skills to face difficult situations (Kuper \& Kuper, 1996, p.98).

Cognitive theory can be used to modify misconceptions and wrong ideas related to the intellectual deviations of university youth and increase their positive knowledge and information towards intellectual security, modify unwanted behaviors and achieve positive behaviors aimed at keeping the youth safe, intellectually and socially and instilling the spirit of citizenship to society and protecting themselves from Cyber bullying .

\section{- Ecological theory}

The ecological theory seeks to understand the nature of social phenomena and focuses on the study of a set of general and basic facts and concepts such as human development processes and problems, and the nature of the dynamic relationship between biological, mental, emotional and social aspects (El Sanhuri, 1998, p.351).

The ecological model contains both treatment and reform by emphasizing and recognizing the functional relationships between people and their social and psychological environments. 


\begin{tabular}{||cr|}
\hline The Egyptian Journal of Social Work (EJSW) https://ejsw.journals.ekb.eg/e \\
ISSN: $2356-9204$ & Vol 11, Issue.1, January2021 \\
\hline
\end{tabular}

The ecological approach is concerned with internal and external factors and also sees people as positive participants in mutual interactions and works to improve the compatibility between people and their environments to achieve an alignment between the needs of the environment and the characteristics of the environment (Zastrow, 2002,p.56).

The university youth is a social format consisting of a set of subformats consisting of the mental- physical-psychosocial, behavioral, emotional and those aspects are in a case of interaction when exposed to cyber bullying, they are psychologically influenced but the impact is different on other aspects, and it also helps in the development and improvement of university youth with the human and physical environment in the sense that the general practitioner should realize that the process of assistance can be given to university youth, with the aim of investing all their capabilities to achieve intellectual security and face Cyber bullying

\section{Methodology}

The study was applied to (378) male and female students at Helwan University. the study was applied in social science faculties (such as the Faculty of Social Work and the Faculty of Commerce) and natural science faculties (such as the Faculty of Pharmacy and the Faculty of medicine) at Helwan University in Cairo, Egypt. The study was implemented during the period from 10/6/2020 to 3/7/202. sampling unit: The number of university youth at theoretical faculties at Helwan University was calculated,$(19,534)$ students, as well as the number of university youth in the practical faculties of Helwan University and their number is (4703) students .And they are distributed as follows.

Table (1) Distribution of Study community university youth

\begin{tabular}{|c|c|c|c|}
\hline No & \multicolumn{2}{|l|}{ Faculty } & university youth number \\
\hline 1 & \multirow[b]{2}{*}{$\begin{array}{l}\text { heoretical } \\
\text { faculties }\end{array}$} & Faculty of Social Work & 7562 \\
\hline 2 & & $\begin{array}{l}\text { Faculty of Commerce and } \\
\text { Business Administration }\end{array}$ & 11972 \\
\hline \multicolumn{3}{|c|}{ theoretical faculties total } & 19534 \\
\hline 1 & \multirow{2}{*}{$\begin{array}{l}\text { Practical } \\
\text { faculties }\end{array}$} & Faculty of Pharmacy & 3078 \\
\hline 2 & & Faculty Of Medicine & 1625 \\
\hline \multicolumn{3}{|c|}{ Practical faculties total } & 4703 \\
\hline \multicolumn{3}{|c|}{ theoretical faculties and Practical faculties total } & 24237 \\
\hline
\end{tabular}

Sample type and size: A stratified systematic sampling, and by applying the optimal sample size formula (Al-Dhayan \& Hassan,20002,P.247) the sample size for university youth was (378), and the Proportional allocation method was used as follows: 


\begin{tabular}{||cr|}
\hline The Egyptian Journal of Social Work (EJSW) https://ejsw.journals.ekb.eg/e \\
ISSN: $2356-9204$ & Vol 11, Issue.1, January2021 \\
\hline
\end{tabular}

Table (2) Distribution of university youth using the optimal sample size formula

\begin{tabular}{|l|l|l|l|l|}
\hline No & Faculty & $\begin{array}{l}\text { university } \\
\text { youth number }\end{array}$ & $\begin{array}{l}\text { optimal } \\
\text { sample size }\end{array}$ \\
\hline 1 & \multirow{2}{*}{$\begin{array}{l}\text { theoretical } \\
\text { faculties }\end{array}$} & Faculty of Social Work & 7562 & 118 \\
\cline { 3 - 5 } & $\begin{array}{l}\text { Faculty of Commerce and } \\
\text { Business Administration }\end{array}$ & 11972 & 187 \\
\hline \multicolumn{2}{|l|}{ total theoretical faculties } & 19534 & 305 \\
\hline 1 & Practical & Faculty of Pharmacy & 3078 & 48 \\
\cline { 2 - 4 } 2 & Faculty Of Medicine & 1625 & 25 \\
\hline \multicolumn{2}{|l|}{ fotal Practical faculties } & 4703 & 73 \\
\hline \multicolumn{2}{|l|}{ total theoretical faculties and Practical faculties } & 24237 & 378 \\
\hline
\end{tabular}

\section{Validity and reliability of the study tools:}

The study is of the descriptive type, based on the social survey method, applied on a sample of Helwan University students from theoretical and practical faculties

The study was based on the intellectual security scale prepared by Dr. Magda Elsayed Ali AlKeshki , Dr. Nagwa Thawab Al-Otaibi ) for youth for 2017 and was modified in accordance with the current study and the scale of Cyber bullying prepared by Dr.Omnia Ibrahim Al-Shenawi (the bullied). Cyber bullying scale among university youth includes (5) dimensions : (Trolling and defamation dimension (8) phrases, Exclusion dimension(5) phrases, Inconvenience and privacy violation dimension(5) phrases, Insult and threat dimension(3) phrases, sexual harassment dimension (5) phrases ,the intellectual security scale among university youth includes (5) dimensions: Citizenship dimension (6) phrases, Religion dimension(7) phrases, Intellectual dimension(11)phrases, Security dimension(6) phrases, Moral dimension (7)phrases

Cyber bullying scale among university youth:

The researcher conducted statistical reliability of the Cyber bullying scale among university youth using the Spearman-Brown Split-Half coefficient by applying it to a sample of (25) university youth (outside the study community but applying the same conditions for the selection of the sample), where the terms of each dimension were divided into two halves, the first section includes the values obtained from the response to the odd phrases, and the second section includes the values expressing the even phrases, and the results of the test came as follows: 


\begin{tabular}{||cr||}
\hline The Egyptian Journal of Social Work (EJSW) https://ejsw.journals.ekb.eg/e \\
ISSN: 2356-9204 & Vol 11, Issue.1, January2021 \\
\hline
\end{tabular}

Table (3) Results of the reliability of Cyber bullying scale among university youth

\begin{tabular}{|l|l|l|}
\hline No & Dimensions & $\begin{array}{l}\text { Spearman-Brown } \\
\text { coefficient }\end{array}$ \\
\hline 1 & Trolling and defamation dimension & 0.95 \\
\hline 2 & Exclusion dimension & 0.93 \\
\hline 3 & Inconvenience and privacy violation dimension & 0.89 \\
\hline 4 & Insult and threat dimension & 0.90 \\
\hline 5 & sexual harassment dimension & 0.88 \\
\hline \multicolumn{2}{|l|}{ Total Cyber bullying scale dimension } & 0.94 \\
\hline
\end{tabular}

Intellectual Security scale among university youth:

The researcher conducted statistical reliability of the Intellectual Security scale among university youth using the Spearman-Brown Split-Half coefficient by applying it to a sample of (25) university youth (outside the study community but applying the same conditions for the selection of the sample), where the terms of each dimension were divided into two halves, the first section includes the values obtained from the response to the odd phrases, and the second section includes the values expressing the even phrases, and the results of the test came as follows:

Table (4) Results of the reliability of Intellectual Security scale among university youth

\begin{tabular}{|l|l|l|}
\hline No & Dimensions & $\begin{array}{l}\text { Spearman-Brown } \\
\text { coefficient }\end{array}$ \\
\hline 1 & Citizenship dimension & 0.91 \\
\hline 2 & Religion dimension & 0.96 \\
\hline 3 & Intellectual dimension & 0.90 \\
\hline 4 & Security dimension & 0.86 \\
\hline 5 & Moral dimension & 0.93 \\
\hline \multicolumn{2}{|l}{ Total Intellectual Security scale dimensions } & 0.95 \\
\hline
\end{tabular}

The previous table shows that: Most of the reliability coefficients for dimensions have a high degree of reliability, so it is possible to rely on determining the level of the cyber bullying scale and the intellectual security scale among university youth, to judge the level of the cyber bullying scale and the scale of intellectual security among university youth, so that the beginning and end of the 5 point scale categories are: strongly agree(five marks), agree (four marks), undecided (three marks),disagree(two marks), strongly disagree(one mark). To determine the length of the 5 point scale cells (minimum and maximum limits), the range was calculated = maximum valueminimum value $(5-1=4)$, then divided on the scale cells to get the length cell debugger $4 / 5=0.8$ ) and then this value was added to the Minimum value in the scale or the beginning of the scale which is 1 . 


\begin{tabular}{||cr|}
\hline The Egyptian Journal of Social Work (EJSW) https://ejsw.journals.ekb.eg/e \\
ISSN: $2356-9204$ & Vol 11, Issue.1, January2021 \\
\hline \hline
\end{tabular}

\section{Results of the Field Study}

: Study community university youth Description

Table (5) Distribution of Study community university youth

\begin{tabular}{|l|l|l|l|l|l|}
\hline \multirow{2}{*}{} & \multirow{2}{*}{ Quantitative Variables } & \multicolumn{2}{l|}{$\begin{array}{l}\text { theoretical faculties } \\
\text { (N=305) }\end{array}$} & \multicolumn{2}{l|}{$\begin{array}{l}\text { Practical faculties } \\
\text { (N=73) }\end{array}$} \\
\cline { 3 - 7 } & $\begin{array}{l}\text { Arithmetic } \\
\text { average }\end{array}$ & $\begin{array}{l}\text { Standard } \\
\text { deviation }\end{array}$ & $\begin{array}{l}\text { Arithmetic } \\
\text { average }\end{array}$ & $\begin{array}{l}\text { Standard } \\
\text { deviation }\end{array}$ \\
\hline 1 & Age & 21 & 1 & 20 & 1 \\
\hline No & Gender & f & $\%$ & f & $\%$ \\
\hline 1 & Male & 121 & 39.7 & 21 & 28.8 \\
\hline 2 & Female & 184 & 60.3 & 52 & 71.2 \\
\hline Total & 305 & 100 & 73 & 100 \\
\hline No & Grade & $\mathrm{f}$ & $\%$ & $\mathrm{f}$ & $\%$ \\
\hline 1 & Grade 1 & 70 & 23 & 21 & 28.8 \\
\hline 2 & Grade 2 & 79 & 25.9 & 19 & 26 \\
\hline 3 & Grade 3 & 82 & 26.9 & 16 & 21.9 \\
\hline 4 & Grade 4 & 74 & 24.3 & 17 & 23.3 \\
\hline \multicolumn{2}{|l|}{ Total } & 305 & 100 & 73 & 100 \\
\hline No & Residence & F & $\%$ & $\mathrm{f}$ & $\%$ \\
\hline 1 & The countryside & 65 & 21.3 & 8 & 11 \\
\hline 2 & city or town & 240 & 78.7 & 65 & 89 \\
\hline \multicolumn{2}{|l|}{ Total } & 305 & 100 & 73 & 100 \\
\hline
\end{tabular}

The previous table shows that: The average age of university youth at theoretical faculties is (21) years, with standard deviation about 1 year. The average age of university youth at practical faculties is (20) years, with standard deviation about 1 year. The largest percentage of university youth at theoretical faculties are females $(60.3 \%)$, then males $(39.7 \%)$. The largest percentage of university youth at practical faculties are females $(71.2 \%)$, then males (28.8\%). The largest percentage of university youth at theoretical faculties is grade $3(26.9 \%)$, then grade $2(25.9 \%)$, then grade $4(24.3 \%)$ and finally grade $1(23 \%)$. The largest percentage of university youth at practical faculties is grade $1(28.8 \%)$, then grade $2(26 \%)$,then grade $4(23.3 \%)$ and finally grade $3(21.9 \%)$. The largest percentage of university youth at theoretical faculties live in cities or towns(78.7\%), then in the countryside $(21.3 \%)$ The largest percentage of university youth at practical faculties live in cities or towns $(89 \%)$ then in the countryside $(11 \%)$. 


\begin{tabular}{||cr||}
\hline \multicolumn{2}{|c|}{ The Egyptian Journal of Social Work (EJSW) https://ejsw.journals.ekb.eg/e } \\
ISSN: $2356-9204$ & Vol 11, Issue.1, January2021 \\
\hline
\end{tabular}

Table (6) the correlation between Cyber bullying and the Intellectual Security among university youth"

\begin{tabular}{|c|c|c|c|c|c|c|c|}
\hline \multirow[b]{2}{*}{ No } & \multirow[b]{2}{*}{ dimensions } & \multicolumn{6}{|c|}{ theoretical faculties $(\mathrm{N}=305)$} \\
\hline & & $\begin{array}{l}\text { Citizenship } \\
\text { dimension }\end{array}$ & $\begin{array}{l}\text { Religion } \\
\text { dimension }\end{array}$ & $\begin{array}{l}\text { Intellectual } \\
\text { dimension }\end{array}$ & $\begin{array}{l}\text { Security } \\
\text { dimension }\end{array}$ & $\begin{array}{l}\text { Moral } \\
\text { dimension }\end{array}$ & \begin{tabular}{|l} 
Total \\
Intellectual \\
Security \\
dimensions \\
\end{tabular} \\
\hline 1 & $\begin{array}{ll}\text { Trolling } & \text { and } \\
\text { defamation } & \\
\text { dimension } & \\
\end{array}$ & $-0.445^{* *}$ & $-0.503 * *$ & $-0.369 * *$ & $-0.453 * *$ & $-0.599 * *$ & $-0.509 * *$ \\
\hline 2 & $\begin{array}{l}\text { Exclusion } \\
\text { dimension }\end{array}$ & $-0.583 * *$ & $-0.597 * *$ & $-0.529 * *$ & $-0.636^{* *}$ & $-0.609 * *$ & $-0.635 * *$ \\
\hline 3 & $\begin{array}{l}\text { Inconvenience } \\
\text { and privacy } \\
\text { violation } \\
\text { dimension }\end{array}$ & $-0.622 * *$ & $-0.628 * *$ & $-0.552 * *$ & $-0.659 * *$ & $-0.667 * *$ & $-0.672 * *$ \\
\hline 4 & $\begin{array}{l}\text { Insult and threat } \\
\text { dimension }\end{array}$ & $-0.690 * *$ & $-0.692 * *$ & $-0.602 * *$ & $-0.732 * *$ & $-0.710 * *$ & $-0.737 * *$ \\
\hline 5 & $\begin{array}{l}\text { sexual } \\
\text { harassment } \\
\text { dimension }\end{array}$ & $-0.709 * *$ & $-0.690 * *$ & $-0.617 * *$ & $-0.748 * *$ & $-0.722 * *$ & $-0.749 * *$ \\
\hline $\begin{array}{l}\text { Total } \\
\text { dimen }\end{array}$ & $\begin{array}{l}\text { Cyber bullying } \\
\text { ions }\end{array}$ & $-0.681 * *$ & $-0.691 * *$ & $-0.596 * *$ & $-0.721 * *$ & $-0.732 * *$ & $-0.734 * *$ \\
\hline
\end{tabular}

\begin{tabular}{|c|c|c|c|c|c|c|c|}
\hline \multirow[b]{2}{*}{ No } & \multirow[b]{2}{*}{ dimensions } & \multicolumn{6}{|c|}{ Practical faculties $(\mathrm{N}=73)$} \\
\hline & & $\begin{array}{l}\text { Citizenship } \\
\text { dimension }\end{array}$ & $\begin{array}{l}\text { Religion } \\
\text { dimension }\end{array}$ & $\begin{array}{l}\text { Intellectual } \\
\text { dimension }\end{array}$ & $\begin{array}{l}\text { Security } \\
\text { dimension }\end{array}$ & $\begin{array}{l}\text { Moral } \\
\text { dimension }\end{array}$ & \begin{tabular}{|l} 
Total \\
Intellectual \\
Security \\
dimensions \\
\end{tabular} \\
\hline 1 & $\begin{array}{l}\text { Trolling and } \\
\text { defamation } \\
\text { dimension }\end{array}$ & $-0.889 * *$ & $-0.839 * *$ & $-0.801 * *$ & $-0.866 * *$ & $-0.885 * *$ & $-0.898 * *$ \\
\hline 2 & $\begin{array}{l}\text { Exclusion } \\
\text { dimension }\end{array}$ & $-0.859 * *$ & $-0.882 * *$ & $-0.802 * *$ & $-0.861 * *$ & $-0.856 * *$ & $-0.893 * *$ \\
\hline 3 & $\begin{array}{l}\text { Inconvenience } \\
\text { and privacy } \\
\text { violation } \\
\text { dimension } \\
\end{array}$ & $-0.906 * *$ & $-0.875 * *$ & $-0.825 * *$ & $-0.861 * *$ & $-0.910 * *$ & $-0.919 * *$ \\
\hline 4 & $\begin{array}{l}\text { Insult and threat } \\
\text { dimension }\end{array}$ & $-0.865 * *$ & $-0.827 * *$ & $-0.791 * *$ & $-0.834 * *$ & $-0.830 * *$ & $-0.869 * *$ \\
\hline 5 & $\begin{array}{l}\text { sexual } \\
\text { harassment } \\
\text { dimension } \\
\end{array}$ & $-0.887 * *$ & $-0.826 * *$ & $-0.815 * *$ & $-0.865 * *$ & $-0.876 * *$ & $-0.895 * *$ \\
\hline $\begin{array}{l}\text { Total } \\
\text { dimen }\end{array}$ & $\begin{array}{l}\text { Cyber bullying } \\
\text { sions }\end{array}$ & $-0.919 * *$ & $-0.885 * *$ & $-0.841 * *$ & $-0.894 * *$ & $-0.909 * *$ & $-0.933 * *$ \\
\hline
\end{tabular}
** significant at $(0.01)$
$*$ significant at $(0.05)$

The previous table shows that: There is a negative correlation that is statistically significant at $(0.1)$ between Cyber bullying and the Intellectual Security among university youth as determined by university youth at theoretical faculties, this may be due to a strong negative correlation between these dimensions and that they reflect what the study aims to achieve. There is a negative correlation that is statistically significant at (0.1) between Cyber bullying and the Intellectual Security among university youth as determined by 


\section{The Egyptian Journal of Social Work (EJSW) https://ejsw.journals.ekb.eg/e}

ISSN: 2356-9204

Vol 11, Issue.1, January2021

university youth at practical faculties, this may be due to a strong negative correlation between these dimensions and that they reflect what the study aims to achieve. This agrees with the study (Khattab 2019 and Ramadan 2019), which confirmed that social networking sites have negative implications for the intellectual security of university youth, social, religious and moral. Also the study (AlHazani 2017), which confirmed the impact of social networking sites on enhancing the intellectual security of female students.

Table (7) simple regression analysis of the correlation between Cyber bullying and the Intellectual Security among university youth"

\begin{tabular}{|l|c|c|c|c|c|l|c|}
\hline $\begin{array}{l}\text { indepen } \\
\text { dent } \\
\text { variable }\end{array}$ & $\begin{array}{l}\text { Research } \\
\text { community }\end{array}$ & $\begin{array}{l}\text { numbe } \\
\mathrm{r}(\mathrm{N})\end{array}$ & $\begin{array}{l}\text { Regres } \\
\text { sion } \\
\text { coeffic } \\
\text { ient B }\end{array}$ & $\begin{array}{l}\mathrm{T}- \\
\text { Test }\end{array}$ & $\begin{array}{l}\text { F- } \\
\text { Test }\end{array}$ & $\begin{array}{l}\text { correlation } \\
\text { coefficient } \\
\mathrm{R} \text {. }\end{array}$ & $\begin{array}{l}\text { Coefficient } \\
\text { determination } \\
\mathrm{R}^{2}\end{array}$ \\
\hline $\begin{array}{l}\text { Total } \\
\begin{array}{l}\text { Cyber } \\
\text { bullying } \\
\text { dimensio } \\
\text { ns }\end{array}\end{array}$ & $\begin{array}{c}\text { theoretical } \\
\text { faculties }\end{array}$ & 305 & -0.615 & $\begin{array}{c}18.833 * \\
*\end{array}$ & $\begin{array}{l}354.681 \\
* *\end{array}$ & $-0.734 * *$ & 0.539 \\
\cline { 2 - 8 } & Practical faculties & 73 & -0.853 & $\begin{array}{c}-1.822 * \\
*\end{array}$ & $* 76.213$ & $-0.933 * *$ & 0.870 \\
\hline
\end{tabular}

** Significant at $(0.01) \quad *$ significant at $(0.05)$

The previous table shows that: simple regression analysis of the correlation between Cyber bullying and the Intellectual Security among university youth as determined by university youth at theoretical faculties:

- The value of correlation coefficient between the independent variable " total cyber bullying among university youth" and the dependent variable " total Intellectual Security among university youth" is (-0.734) which is statistically significant at (0.01), indicating a negative correlation between the two variables.

- (F) test result ( $\mathrm{Sig}=0.000, \mathrm{~F}=354.681$ ), shows the significance of the regression model ,the value of the Coefficient of determination is (0.539), which means total cyber bullying explains (53.9\%) of changes in Intellectual Security among university youth.

- The value of the Coefficient of determination is (-0.615), which shows positive correlation between the independent variable and the dependent variable, $\mathrm{T}$ test result $(\mathrm{Sig}=0.000, \mathrm{~T}=-18.833)$ shows that the effect of the independent variable on the dependent variable is statistically significant at(0.01).

- This makes us accept the first hypothesis of the study "There is a negative correlation that is statistically significant between Cyber bullying and the Intellectual Security among university youth". 


\begin{tabular}{||cr|}
\hline The Egyptian Journal of Social Work (EJSW) https://ejsw.journals.ekb.eg/e \\
ISSN: 2356-9204 & Vol 11, Issue.1, January2021 \\
\hline \hline
\end{tabular}

- simple regression analysis of the correlation between Cyber bullying and the Intellectual Security among university youth as determined by university youth at practical faculties:

- The value of correlation coefficient between the independent variable " total cyber bullying among university youth" and the dependent variable " total Intellectual Security among university youth" is (-0.933) which is statistically significant at $(0.01)$, indicating a negative correlation between the two variables.

- (F) Test result ( $\mathrm{Sig}=0.000, \mathrm{~F}=476.213$ ), shows the significance of the regression model ,the value of the Coefficient of determination is (0.870), which means total cyber bullying explains $(87 \%)$ of changes in Intellectual Security among university youth.

- The value of the Coefficient of determination is (-0.853), which shows positive correlation between the independent variable and the dependent variable, $\mathrm{T}$ test result $(\mathrm{Sig}=0.000, \mathrm{~T}=-21.822$ ) shows that the effect of the independent variable on the dependent variable is statistically significant at (0.01).

- This makes us accept the first hypothesis of the study "There is a negative correlation that is statistically significant between Cyber bullying and the Intellectual Security among university youth"

Table (8) the significant differences between the averages of grades of the university youth at theoretical faculties and practical faculties on the scale of Cyber bullying. ( $\mathrm{N}=378)$

\begin{tabular}{|c|c|c|c|c|c|c|c|c|}
\hline No & Dimensions & $\begin{array}{l}\text { Research } \\
\text { community }\end{array}$ & number(N) & $\begin{array}{l}\text { Arithmetic } \\
\text { average }\end{array}$ & $\begin{array}{l}\text { Standard } \\
\text { deviation }\end{array}$ & $\begin{array}{l}\text { Degree } \\
\text { of } \\
\text { freedom } \\
\text { (df) }\end{array}$ & $\begin{array}{l}\mathbf{T} \\
\text { value }\end{array}$ & indication \\
\hline \multirow{2}{*}{1} & \multirow{2}{*}{$\begin{array}{l}\text { Trolling and } \\
\text { defamation } \\
\text { dimension }\end{array}$} & $\begin{array}{l}\text { theoretical } \\
\text { faculties }\end{array}$ & 305 & 2.44 & 0.97 & \multirow{2}{*}{376} & \multirow{2}{*}{-16.000} & \multirow{2}{*}{$* *$} \\
\hline & & $\begin{array}{l}\text { Practical } \\
\text { faculties }\end{array}$ & 73 & 4.42 & 0.83 & & & \\
\hline \multirow{2}{*}{2} & \multirow{2}{*}{$\begin{array}{l}\text { Exclusion } \\
\text { dimension }\end{array}$} & $\begin{array}{l}\text { theoretical } \\
\text { faculties }\end{array}$ & 305 & 2.33 & 1.1 & \multirow{2}{*}{376} & \multirow{2}{*}{-16.206} & \multirow{2}{*}{$* *$} \\
\hline & & $\begin{array}{l}\text { Practical } \\
\text { faculties }\end{array}$ & 73 & 4.5 & 0.67 & & & \\
\hline \multirow{2}{*}{3} & \multirow{2}{*}{$\begin{array}{c}\text { Inconvenience } \\
\text { and privacy } \\
\text { violation } \\
\text { dimension }\end{array}$} & $\begin{array}{c}\text { theoretical } \\
\text { faculties }\end{array}$ & 305 & 2.4 & 1 & \multirow{2}{*}{376} & \multirow{2}{*}{-15.862} & \multirow{2}{*}{$* *$} \\
\hline & & $\begin{array}{l}\text { Practical } \\
\text { faculties }\end{array}$ & 73 & 4.39 & 0.78 & & & \\
\hline \multirow{2}{*}{4} & \multirow{2}{*}{$\begin{array}{c}\text { Insult and } \\
\text { threat } \\
\text { dimension }\end{array}$} & $\begin{array}{l}\text { theoretical } \\
\text { faculties }\end{array}$ & 305 & 2.01 & 1.31 & \multirow{2}{*}{376} & \multirow{2}{*}{-15.440} & \multirow{2}{*}{$* *$} \\
\hline & & $\begin{array}{l}\text { Practical } \\
\text { faculties }\end{array}$ & 73 & 4.48 & 0.77 & & & \\
\hline \multirow{2}{*}{5} & \multirow{2}{*}{$\begin{array}{c}\text { sexual } \\
\text { harassment } \\
\text { dimension }\end{array}$} & $\begin{array}{l}\text { theoretical } \\
\text { faculties }\end{array}$ & 305 & 2.11 & 1.42 & \multirow{2}{*}{376} & \multirow{2}{*}{-13.629} & \multirow{2}{*}{$* *$} \\
\hline & & $\begin{array}{l}\text { Practical } \\
\text { faculties }\end{array}$ & 73 & 4.47 & 0.8 & & & \\
\hline \multirow{2}{*}{\multicolumn{2}{|c|}{$\begin{array}{l}\text { Total Cyber bullying } \\
\text { dimensions }\end{array}$}} & $\begin{array}{c}\text { theoretical } \\
\text { faculties }\end{array}$ & 305 & 2.26 & 1.06 & \multirow{2}{*}{376} & \multirow{2}{*}{-16.713} & \multirow{2}{*}{$* *$} \\
\hline & & $\begin{array}{l}\text { Practical } \\
\text { faculties }\end{array}$ & 73 & 4.45 & 0.74 & & & \\
\hline
\end{tabular}




\begin{tabular}{||cr||}
\hline \multicolumn{2}{|c||}{ The Egyptian Journal of Social Work (EJSW) https://ejsw.journals.ekb.eg/e } \\
ISSN: $2356-9204$ & Vol 11, Issue.1, January2021 \\
\hline
\end{tabular}

The previous table shows that: There are differences that are statistically significant at $(0.01)$ between the averages of grades of the university youth at theoretical faculties and practical faculties on the Cyber bullying scale dimensions, (Trolling and defamation dimension, Exclusion dimension, Inconvenience and privacy violation dimension, Insult and threat dimension, sexual harassment dimension and Total Cyber bullying dimensions) in favour of the responses of university youth at practical faculties. This makes us accept the second hypothesis of the study." There are statistically significant differences between the averages of grades of the university youth at theoretical faculties and practical faculties on the scale of Cyber bullying"

Table (9) The significant differences between the averages of grades of the university youth at theoretical faculties and practical faculties on the scale of the Intellectual Security. $(\mathrm{N}=378)$

\begin{tabular}{|c|c|c|c|c|c|c|c|c|}
\hline No & Dimensions & $\begin{array}{l}\text { Research } \\
\text { community }\end{array}$ & $\begin{array}{l}\text { Num } \\
\text { ber } \\
(\mathrm{N})\end{array}$ & $\begin{array}{l}\text { Arithmet } \\
\text { ic } \\
\text { average }\end{array}$ & $\begin{array}{l}\text { Standard } \\
\text { deviation }\end{array}$ & $\begin{array}{l}\text { Degree } \\
\text { of } \\
\text { freedom } \\
\text { (df) }\end{array}$ & T value & $\begin{array}{l}\text { indica } \\
\text { tion }\end{array}$ \\
\hline \multirow{2}{*}{1} & \multirow{2}{*}{$\begin{array}{l}\text { Citizenship } \\
\text { dimension }\end{array}$} & $\begin{array}{l}\text { theoretical } \\
\text { faculties }\end{array}$ & 305 & 3.92 & 1.08 & \multirow{2}{*}{376} & \multirow{2}{*}{17.784} & \multirow{2}{*}{$* *$} \\
\hline & & $\begin{array}{l}\text { Practical } \\
\text { faculties }\end{array}$ & 73 & 1.56 & 0.71 & & & \\
\hline \multirow{2}{*}{2} & \multirow{2}{*}{ Religion dimension } & $\begin{array}{l}\text { theoretical } \\
\text { faculties }\end{array}$ & 305 & 3.99 & 1.04 & \multirow{2}{*}{376} & \multirow{2}{*}{18.712} & \multirow{2}{*}{$* *$} \\
\hline & & $\begin{array}{l}\text { Practical } \\
\text { faculties }\end{array}$ & 73 & 1.59 & 0.72 & & & \\
\hline \multirow{2}{*}{3} & \multirow{2}{*}{$\begin{array}{l}\text { Intellectual } \\
\text { dimension }\end{array}$} & $\begin{array}{l}\text { theoretical } \\
\text { faculties }\end{array}$ & 305 & 3.43 & 0.88 & \multirow{2}{*}{376} & \multirow{2}{*}{17.53} & \multirow{2}{*}{$* *$} \\
\hline & & $\begin{array}{l}\text { Practical } \\
\text { faculties }\end{array}$ & 73 & 1.52 & 0.61 & & & \\
\hline \multirow{2}{*}{4} & \multirow{2}{*}{ Security dimension } & $\begin{array}{l}\text { theoretical } \\
\text { faculties }\end{array}$ & 305 & 3.76 & 0.98 & \multirow{2}{*}{376} & \multirow{2}{*}{18.037} & \multirow{2}{*}{$* *$} \\
\hline & & $\begin{array}{l}\text { Practical } \\
\text { faculties }\end{array}$ & 73 & 1.56 & 0.7 & & & \\
\hline \multirow{2}{*}{5} & \multirow{2}{*}{ Moral dimension } & $\begin{array}{l}\text { theoretical } \\
\text { faculties }\end{array}$ & 305 & 3.76 & 0.79 & \multirow{2}{*}{376} & \multirow{2}{*}{21.227} & \multirow{2}{*}{$* *$} \\
\hline & & $\begin{array}{l}\text { Practical } \\
\text { faculties }\end{array}$ & 73 & 1.58 & 0.78 & & & \\
\hline \multirow{2}{*}{\multicolumn{2}{|c|}{$\begin{array}{l}\text { Total Intellectual Security } \\
\text { dimensions }\end{array}$}} & $\begin{array}{l}\text { theoretical } \\
\text { faculties }\end{array}$ & 305 & 3.77 & 0.89 & \multirow{2}{*}{376} & \multirow{2}{*}{19.919} & \multirow{2}{*}{$* *$} \\
\hline & & $\begin{array}{l}\text { Practical } \\
\text { faculties }\end{array}$ & 73 & 1.56 & 0.67 & & & \\
\hline
\end{tabular}

** significant at $(0.01)$

The previous table shows that:

There are differences that are statistically significant at (0.01) between the averages of grades of the university youth at theoretical faculties and practical faculties on the Intellectual Security scale dimensions .(Citizenship dimension ,Religion dimension, Intellectual dimension, Security dimension, Moral dimension and Total Intellectual Security dimensions) in favour of the responses of university youth at theoretical faculties. This makes us accept the third hypothesis of the study. "There are statistically significant differences 


\section{The Egyptian Journal of Social Work (EJSW) https://ejsw.journals.ekb.eg/e}

ISSN: 2356-9204

Vol 11, Issue.1, January2021

between the averages of grades of the university youth at theoretical faculties and practical faculties on the scale of the Intellectual Security".

Table (10) the significant differences between the averages of grades of the university youth at practical faculties and theoretical faculties on the scale of Cyber bullying.

\begin{tabular}{|c|c|c|c|c|c|c|c|c|}
\hline Dimensions & & $\begin{array}{l}\text { Researc } \\
\mathrm{h} \\
\text { commu } \\
\text { nity }\end{array}$ & $\begin{array}{l}\text { num } \\
\text { ber( } \\
\mathrm{N})\end{array}$ & $\begin{array}{l}\text { Arithm } \\
\text { etic } \\
\text { average }\end{array}$ & $\begin{array}{l}\text { Standar } \\
\mathrm{d} \\
\text { deviatio } \\
\mathrm{n}\end{array}$ & $\begin{array}{l}\text { Degre } \\
\text { e of } \\
\text { freedo } \\
m(d f)\end{array}$ & $\mathrm{T}$ value & $\begin{array}{l}\text { indicati } \\
\text { on }\end{array}$ \\
\hline theoretical & \multirow{4}{*}{$\begin{array}{l}\text { Total Cyber } \\
\text { bullying } \\
\text { dimensions }\end{array}$} & Males & 121 & 2.48 & 1.17 & \multirow{2}{*}{303} & \multirow{2}{*}{3.001} & \multirow{2}{*}{$* *$} \\
\hline $\begin{array}{l}\text { faculties } \\
\mathrm{N}=(305)\end{array}$ & & Females & 184 & 2.11 & 0.96 & & & \\
\hline \multirow{2}{*}{$\begin{array}{l}\text { Practical } \\
\text { faculties } \\
N=(73)\end{array}$} & & Males & 21 & 4.33 & 0.87 & \multirow{2}{*}{71} & \multirow{2}{*}{-0.899} & \multirow{2}{*}{$\begin{array}{c}\text { insignifica } \\
\text { nt }\end{array}$} \\
\hline & & Females & 52 & 4.5 & 0.68 & & & \\
\hline
\end{tabular}

** significant at $(0.01)$

* significant at $(0.05)$

The previous table shows that:

- There are statistically significant differences between the averages of grades of the university youth males and females at theoretical faculties on the Total Cyber bullying scale dimensions in favour of the responses of male university youth at theoretical faculties.

- "There are no statistically significant differences between the averages of grades of the university youth males and females at practical faculties on the Total Cyber bullying scale dimensions.

- This makes us accept the fourth hypothesis of the study. "There are statistically significant differences between the averages of grades of the university youth males and females at theoretical faculties and practical faculties on the scale of Cyber bullying “

\section{- Discussion of the results:}

The study has sought to try testing the hypotheses to find out what the relationship between cyber bullying and the intellectual security of university youth and try to set indicators for social workers to enhance the intellectual security of university youth and face cyber bullying directed at university youth through social media whether Internet, Face book, whatsapp, mobile phones or text messages and the study concluded that there is a negative correlation between Cyber bullying and the Intellectual Security of university youth which means that the more cyber bullying there is, the more it affects the intellectual security of university youth, this agrees with the study( AlMeazer,2015) which confirmed that social networking sites have a major influence on the intellectual security of female university students , also the study (Khattab, 2019 ), which confirmed that social networking sites have negative implications for the intellectual 
security of university youth, social, psychological, economic, religious and moral, the most important implications are the marketing of values that contradict the recognized social values and customs,

Also (Al-Hazani, study, 2017), which confirmed the influence of social networking sites on estimating the intellectual security among the female students of The University of Princess Nourah Bint Abdul Rahman.

Also the study (Mohamed, 2013) which showed the importance of the role of the university in enhancing the concept of the intellectual security of university youth and highlighting the role of faculty staff member in effecting intellectual security and confirmed the importance of the role of faculty staff member to the intellectual education of students through establishing the principles of moderation and reasonableness in their beliefs and actions. Also the study(Mansour,2017) which aimed at the evaluation of the role that the university must play in achieving intellectual security from the point of view of the teaching staff and students. The study has found preventive methods which must be adopted to highly effect intellectual security.

Cyber bullying is one of the problems that result from social media, which are used by university youth whose intellectual security is influenced by the social media, and this agrees with the study (Eid 2019), which confirmed that Cyber bullying of university youth causes many behaviors such as insult, threat and defamation. Thus, cognitive theory seeks to monitor negative effects resulting from Cyber bullying, modify misconceptions and wrong ideas related to the intellectual deviations, modify unwanted behaviors, achieve positive behaviors aimed at securing the thinking of university youth and face Cyber bullying they are exposed to, as university youth is a format consisting of a set of sub-formats consisting of the mental- physicalpsychosocial, behavioral and emotional, when exposed to cyber bullying, their psychological aspects and other aspects are influenced, and this is what has been confirmed by the ecological theory.

In light of the results of the current study and previous studies, the social worker's indicators are determined as a general practitioner in social work to enhance intellectual security and face cyber bullying: as follows: 
The Egyptian Journal of Social Work (EJSW) https://ejsw.journals.ekb.eg/e

ISSN: 2356-9204

Vol 11, Issue.1, January2021

1- Enhancing the intellectual security of university youth through

- Special units at the faculties and university administration conduct training courses and workshops to enhance the intellectual security of university youth.

- Social workers encourage students to participate in the university's student activities to develop their citizenship and religious and intellectual interests.

- Cooperation with faculty staff to develop the thinking of university youth within the classrooms and this has been confirmed by previous studies stressing the importance of the role of faculty staff member in enhancing the intellectual security of university youth.

- Conducting awareness seminars within universities to enhance the intellectual security of university youth.

\section{2- Indicators of facing Cyber bullying}

Educating university youth about the importance of securing their social media accounts and refusing to accept any anonymous friendships.

Providing awareness programs to prevent university youth from being exposed to cyber bullying.

Dealing with students who have been bullied and help them solve their problems

Youth should be aware not to post their private pictures on social media pages so that they will not be harmed by unknown persons.

\section{References:}

Abdullah, A. S. (2017). The role of Egyptian universities in achieving intellectual security for their students, Al-Azhar University, Faculty of Education Journal, No. 35, vol. 3.

Abdul Jawad, A. S. (2017). The intellectual security and its relation to both emotional intelligence and decision making among Cairo University students, Journal of Psychological Counseling, Ain Shams University, Center for Psychological Counseling.

Abdul Rahim.J.K.(2018).Planning indicators to enhance the dimensions of intellectual security for university youth, the Egyptian Association of Social Workers, No. 60, vol. 6.

Al-Dhayan .S D, \& Hassan. A. A. (2002).Data processing using SPSS 10 (Riyadh, Systematic Research Series.

Al-Hazani. N. N. (2017). Social networks and their impact on enhancing intellectual security among students of Princess Nourah bint Abdul-Rahman University, Saudi Arabia, King Fahd National Library Magazine, vol .23, No. 1.

Ali, M. A. ( 2008). Social work and the fields of professional practice, Cairo, ZahraaEl- Shareq Library. 


\section{The Egyptian Journal of Social Work (EJSW) https://ejsw.journals.ekb.eg/e}

ISSN: 2356-9204

Vol 11, Issue.1, January2021

Arabic Glossary, Al Wagieeze. (1997). Dar Al Tahrir, Publishing and Printing.

Alosaimi.B.J\&Sufyani.D.B. (2018). The intellectual security concepts in The English text Books of The intermediate stage in Saudi Arabia an analytical study international interdisciplinary, Journal of education.

Awad. A .G.(2017). Towards a Proposed Concept of the Role of the Community Specialist to Enhance the Intellectual Security of University Youth, Journal of Social Work, Egyptian Society of Social Workers, Egypt.No.57,vol.9.

Barlinska.J\& Szuster.A and Winiewski.M.(2018). Cyber bullying Among Adolescent Bystanders: Role of Affective Versus Cognitive Empathy in Increasing Prosocial Cyber bystander Behavior, Journal list front psychol v.g.

Basyouni .S.S\&Alharbi.A.M.(2020). Cyber Bullying and Its Relationship with The Psychological Unity among The Students of College of Education at Umm ALQura University, Journal of Educational And Psychological sciences,vol.4.

Eid.M.O.(2019). The reality of electronic bullying on social networks between university students, Fayoum, Educational Journal, Faculty of Education, No. 65.

El Sanhuri, A. M. (1998).Approaches, theories, and models of contemporary practice of social service, Cairo, Arab Renaissance House.

Gad. Y.A\& Ahmed. I.S.(2019). The Relationship between the Use Social Networking Sites and Intellectual Security among Students of Social Work, Egyptian Journal of Social Work (EJSW).vol.8.

Central Agency for Public Mobilization and Statistics.( 2018).Cairo , information center for the general population of Egypt

Jadallah S. H. (2018). A proposed program from the perspective of the general practice of social service in developing the awareness of university youth on intellectual security, Journal of the Egyptian Society of Social Workers, No. 59, vol. 1

Khattab, S.A,\& Ramadan.G.J. (2019). The repercussions of social networks on intellectual security among students of colleges of education at Al-Azhar University from the viewpoint of faculty members, the faculty of education, the educational journal, No. 58

Kuper,A\& Kuper.J.(1996).The social science encyclopedia, London, New yourk, second edition

Magsi .H,\& Agha .N and Magsi.I.(2017).Understanding cyber bullying In Pakistani context causes And Effects on young female university students in Sindh province, the free library.

Mansour, M.M. (2017).Evaluating the university's role in achieving intellectual security for its students from their viewpoint and faculty members, Al-Azhar University, Journal of the College of Education, No. 172, vol. 1

Mohammed. A. R. (2013). The role of the university in the activation of intellectual security for its students a field study, Educational Journal, Sohag University, Faculty of Education, No. 33, January.

Muaither, R A. (2015). The impact of social networks on the intellectual security of students at the university level, Al-Azhar University, College of Education Journal, No. 164, vol. 2

Miller, J. D., \& Hufstedler, S. M. (2009). Cyber bullying knows no borders. conference of the Australian Teacher Education Association (ATEA), Albury, 28 June -1 July. 
The Egyptian Journal of Social Work (EJSW) https://ejsw.journals.ekb.eg/e ISSN: 2356-9204 Vol 11, Issue.1, January2021

Schrader .E.(2004).Intellectual Safety, Moral Atmosphere, and Epistemology in College Classrooms, Journal of Adult Development, Vol. 11, No. 2.

Zastrow, C.(2002) . Introduction to Social Work And Social Welfare , New York, Thomson, publishing Company

Zhang, A.T\&, Wee Land.L.P.and DickL.G.(2010).Key Influences of Cyber bullying for University Students, Asia Conference on Information Systems (PACIS) at AIS Electronic Library (AISeL). 